\title{
Use of forest land for national-priority infrastructures in Nepal
}

\begin{abstract}
U. R. Sharma ${ }^{1}$
Forest conversion has been identified as one of the several bottlenecks affecting upon the major infrastructure projects in Nepal, especially in the energy and transport sectors. Nepal's policy requires at least $40 \%$ of its land cover under forest. This means if any forest land is converted to non-forest land, it must be compensated with an equivalent area, preferably in the similar ecotype in the nation. In addition, a specified number of trees must be planted for the number of trees felled in the project site, and the site must be managed and protected for five years by the developers. These provisions have led to growing resentment between the developers and the Ministry of Forests and Soil Conservation (MFSC), leading to delay in providing forest lands for infrastructure projects. With a view to develop mechanisms for the government to rapidly provide forest land for nationally important infrastructure projects, the Government databases were examined to analyze the forests handed over to the developers for non-forestry uses. The data showed that a total of 14,028.4 ha of forest area were handed over to the developers for non-forestry uses until the end of 2015. On an average, 263.8 ha forest area was found to be handed over to the developers between the period of 2010-2013. However, there is a declining trend of forest handed over for non-forestry purposes in the recent years. The decline could be due to the strict enforcement of the legal provision which limits the conversion of forest areas to non-forest areas except in the case of the "national priority projects". It has been recommended that the conversion of forest for infrastructure development should be examined with a holistic perspective by taking all the related components of forest conversion into consideration, from providing forest land for replacement planting. It is recommended that the Forest Product Development Board (FPDB), a parastatal organization under the MFSC, should be entrusted with the work of plantation related to forest conversion. The fund for this work should flow directly from the developers to the FPDB. The possibility of forming a land bank to facilitate the work of the FPDB is also recommended.
\end{abstract}

Key words: Forest clearance, forest conversion, infrastructure, land bank, plantation

$\mathrm{N}$ epal's $40.3 \%$ of land is covered with forest (DFRS, 2015). Forest has remained the backbone for development, especially for the sectors such as agriculture, environment, tourism and infrastructure. Forest sector contributes significantly to the national economy, but the contributions are mostly in the form of intangible benefits.

"Land acquisition, right-of-way and forest clearance delays" has been identified as one of the several bottlenecks affecting upon major infrastructure projects in Nepal, especially in the energy and transport sectors (APPIIC, 2016). These bottlenecks affect upon the national- pride projects. With regard to the three subcomponents of the bottleneck related to land, the topic of discussion in this paper is related to forest clearance and land replacement.

Forest lands are managed by two separate government agencies- the Department of Forests (DoF) and the Department National Parks and Wildlife Conservation (DNPWC), both under the Ministry of Forests and Soil Conservation. The DoF manages its forest areas under the provisions of the Forest Act, 1993 (MFSC, 1993) while the DNPWC manages its forest areas under the provisions of the National Parks and Wildlife Conservation Act, 1973 (MFSC, 1973). As the

' Freelance Researcher, Kathmandu, Nepal Email: udayshar@gmail.com 
provisions in these two Acts in providing land for non-forest uses are different or non-existent, the processes of seeking clearance are different. There are several ambiguities and lack of clear directions if such lands can be converted for nonforestry uses in the case of protected areas.

The forest policy of Nepal states that the nation will maintain at least $40 \%$ of its land under forest (MFSC, 2014). It creates a situation that forest cannot be converted for non-forestry uses unless at least an equivalent area, preferably of similar ecotype, are added somewhere else in the nation. In addition, the developers are required to plant 25 times the number of trees felled in the leased forest land (MFSC, 2006). The number of trees required to be planted for one tree $(>10 \mathrm{~cm}$ diameter) felled is usually 25 . However, the number has been reduced to 2 in the case of the hydro power projects keeping in view the energy crisis in the nation. Several officials share their views that modalities of doing this type of swapping areas and planting trees are being done on ad hoc basis without any specific policy or legislative support. There is a growing resentment from developers against the requirement of procuring equivalent private land in the similar ecological zone, plant trees on that land, manage and protect the site for five years (APPIIC, 2017). The Investment Board of Nepal (IBN) and several other government agencies associated with the development sectors have expressed that this requirement of the MFSC should be revised, and the MFSC should accept cash compensation for the use of forestland (APPIIC, 2017). Several attempts have been made in the past to resolve these issues mentioned in the Forest Land Handover Guidelines, 2006 of the Government of Nepal.

The objective of this study was to develop mechanisms for the government to rapidly provide forest land for nationally important infrastructure projects, and to effectively manage the new sites received as compensation.

\section{Materials and methods}

The information needed for this study was gathered from the analyses of data available in the government databases, especially setup for the forests handed over for non-forestry purposes. The deliberations in the consultation workshop jointly organized by the MFSC and the Accelerating Private and Public Investment in Infrastructure Component (APPIIC), Department for International Development (DFID)on January 5, 2017 in Kathmandu also provided materials for discussion.

\section{Results and discussion}

\section{Forest lands handed over for non-forestry uses}

The cases of handing over of the forestlands for non-forestry uses have been recorded in the DoF Database, 2015. The Database consists of the records from the Fiscal Years 2005/06 to 2015/16. During this period, there were 385 such cases, totaling $14,028.3$ ha (Table 1). The database does not seem to be complete; however, it provides an indication of demand for forest for non-forestry uses over the periods.

Table 1: Forest land handed over for various purposes during the period of 2005/06-2015/16

\begin{tabular}{llr}
\hline S.N. & Category & Area (ha) \\
\hline 1. & $\begin{array}{l}\text { Tourism-related: resorts, } \\
\text { hotels, cable-cars and parks }\end{array}$ & 199.4 \\
2. & Plantations \\
3. & $\begin{array}{l}\text { Energy: hydropower plants, } \\
\text { transmission lines and tunnels }\end{array}$ & 1690.4 \\
4. & Herb plantations and gardens & 256.0 \\
5. & $\begin{array}{l}\text { Office buildings and } \\
\text { municipality/VDC projects }\end{array}$ & 3724.6 \\
6. & Cement industries and \\
& quarries \\
7. & Wildlife farms \\
8. & Resettlements \\
9. & Communication towers \\
10. & Nepal Army \\
11. & Police \\
12. & Social work, hospitals and & 256.4 \\
& schools & 11.8 \\
13. & Drinking water, roads and & \\
& irrigation channels & \\
\hline & Total $\quad$ Source: DoF Database, 2015
\end{tabular}

Similarly, the MFSC Database (2015) shows the size of forest areas handed over for non-forestry uses during the period of 2010-2013; the forest areas so handed over ranged from 0.003 ha to 147.610 ha. The forest patches were handed over for different purposes such as hydropower generation, transmission lines, public buildings, waste disposal, city parks, mining for cement 
industries, landfill sites, settlements, sites for factory, drinking water supplies, cableway construction, construction of towers for communication, irrigation canals and roads. The analysis of the data showed that the area of forest converted to non-forestry uses was 263.8 ha per year, on an average, ranging from 84.1 ha in 2010 to 518.7 ha in 2011 (Fig. 1).

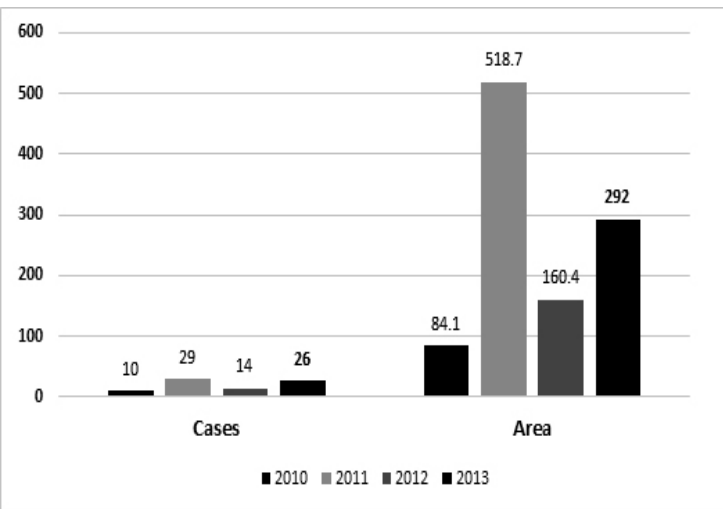

Fig. 1: Forest patches handed over for infrastructure projects during 2010-2013 (MFSC Database, 2015)

Table 2 reflects a declining trend of forest handover for non-forestry uses. This may be because the forest patches handed over in the recent years are less for resettlement purposes, and the government seems strictly enforcing the provision of not providing forest land for projects that cannot qualify as "nationally important". Also, a close examination of data between the two databases (MFSC and DoF) shows that none of the two databases is entirely complete and there are several entries missing in both the databases. Nevertheless, the data can provide an overview of the situation, and throw lights on emerging trends.

Table 2: Total Forest/Forest land handed over to non-forestry uses during the period of 2011/12-2014/15

\begin{tabular}{|c|c|c|c|}
\hline S.N. & Fiscal Year & $\begin{array}{c}\text { Number of } \\
\text { reported cases }\end{array}$ & Area (ha) \\
\hline$\overline{1 .}$ & $2011 / 2012$ & 19 & 642.5 \\
\hline 2. & $2012 / 2013$ & 19 & 447.5 \\
\hline 3. & $2013 / 2014$ & 20 & 245.9 \\
\hline 4. & $2014 / 2015$ & 16 & 137.5 \\
\hline & Total & & 1473.4 \\
\hline
\end{tabular}

There were only a few cases of handing over the forest patches for infrastructure development projects; infrastructures are defined as nationally important roads, bridges, irrigation canals, drinking water supplies, telecommunication towers, transmission lines, hydropower dams, sites for industries and alike. So far, the largest areas of forest handed over for infrastructure development projects were in the F.Y. 2011/12 (598.1 ha) followed by the F.Y. 2008/09 (502.8 ha, Table 3). The handover of the forest areas had sharply declined during 2014-2016.

Table 3: Total Forest land handed for infrastructure development during the period of 2006/2007-2015/2016

\begin{tabular}{llcr}
\hline S.N. & Fiscal Year & $\begin{array}{c}\text { Number of } \\
\text { reported cases }\end{array}$ & Area (ha) \\
\hline 1. & $2006 / 2007$ & 10 & 231.7 \\
2. & $2007 / 2008$ & 6 & 77.1 \\
3. & $2008 / 2009$ & 21 & 502.8 \\
4. & $2009 / 2010$ & 2 & 7.0 \\
5. & $2010 / 2011$ & 5 & 38.2 \\
6. & $2011 / 2012$ & 14 & 598.1 \\
7. & $2012 / 2013$ & 14 & 353.5 \\
8. & $2013 / 2014$ & 15 & 238.3 \\
9. & $2014 / 2015$ & 10 & 79.8 \\
10. & $2015 / 2016$ & 4 & 10.3 \\
& Total & \multicolumn{1}{c}{$\mathbf{2 3 1 . 6 8}$} \\
\hline & Average & \multicolumn{2}{c}{}
\end{tabular}

\section{Discussion and recommendations}

\section{Problem Context}

The MFSC, in the recent past, had a field-based evaluation of the execution of forest conversion decisions with respect to the infrastructure development. It was found that the agreed terms and conditions between the infrastructure projects and the GoN were not fully implemented. The sites received from the developer for plantation as compensation were mostly never planted. Several sites were illegally encroached by squatters. The promised investment for plantation and supervision hardly materialized with the responsible district offices. On the other hand, the lease payments were overdue (MFSC, 2014). All these lapses have prompted the MFSC to review the entire process of providing forest land on lease for infrastructure development. 
The Forest Act, 1993 has a provision of Article 68 , to make forest land available for infrastructure development if the project meets the following three criteria: (i) It is a nationally important project, (ii) It makes no significant environmental impact, and (iii) There is no alternative other than using the forest land. These provisions are further clarified in the Guidelines entitled, "Work Policy to Make Forest Land Available for Other Purposes" (MFSC, 2006). The implementation of the Guidelines has greatly helped, but still there are delays due to ambiguities as explained above.

The National Parks and Wildlife Conservation Act, 1973 has not made a very explicit provision for granting Protected Area (PA) land for infrastructure development. The Article 6 of the Act has been interpreted for granting PA land for this purpose. Another Guidelines entitled "Work Policy on Infrastructure Development and Operation within Protected Areas" (MFSC, 2009) has been under implementation; PA land can be granted under the provisions of this Guidelines. However, there are several issues related to this Guidelines, which need to be resolved.

Conversion of forest land for infrastructure development should not be only viewed from the perspective of infrastructure project. Unless all the components of forest conversion, from providing forest land to replanting and managing the new sites received or procured as compensation are addressed, it would be incomplete. In the absence of such a holistic approach, the problems of delayed forest clearance will continue to prevail.
With the holistic approach, the project can avoid creating a large ecological footprint despite cutting down trees and removing vegetation from the ground. This is because an equivalent private land is added somewhere else in the country, most likely in the lowlands, where the growth of vegetation is faster than the one in the mountains. In the case of hydropower projects, there is an added carbon sequestration benefit as the use of power in the country reduces the consumption of firewood.

\section{Plantation management through Forest Product Development Board}

To resolve the issue of forest conversion and to make it a complete package, the role of Forest Product Development Board (FPDB) becomes important. The FPDB has been an institution under the MFSC which has extensive experience in block planting and managing the plantations over several decades. One of its successful projects is the Sagarnath Plantation (falling mostly in the Sarlahi and Mahottari districts located in the southern part of the Central Development Region of Nepal), where it had planted trees in more than 10,500 ha of land, and has been managing the site since 1981 (FPDB, 2016). In 2017, the APPIIC has proposed a management model (Fig. 2), which provides key functions of planting trees and managing such sites for the FPDB. The model proposes that the fund for such work would directly go to the FPDB from the developers who are required to provide land compensation for using forest land.

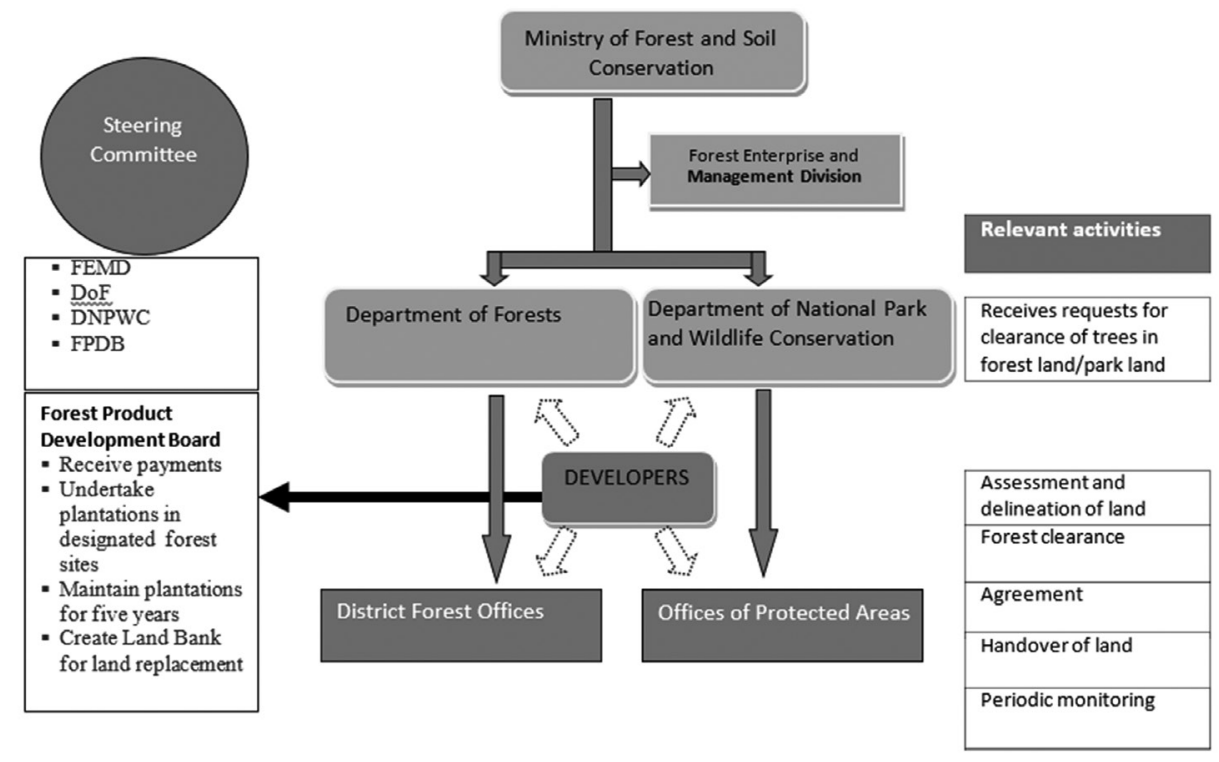

Fig. 2: Proposed Mechanism of Land Replacement (Source: APPIIC, 2017) 


\section{Establishment of a land bank}

The MFSC is also exploring the possibility of creating a land bank to facilitate the work of the FPDB. The land bank, if approved by the GoN, would be established after acquiring about 100 ha of private land in a block from the money FPDB would receive as soft loan or as disbursement from the Government. The proponents of infrastructure, who are required to make land compensation, would buy land from the land bank and would enable FPDB to gradually pay back loan and recover the administrative expenses. This modality would greatly help cut down delays in obtaining forest land for national priority projects.

\section{Recommendations}

In order to rapidly provide forest land for nationally important projects, the MFSC must act to harmonize procedures within the Ministry and with the other related ministries. It should undertake legal reforms in the relevant Acts, Regulations and Work Policies in order to facilitate the concerned departments (DoF and DNPWC) to process requests without any delay. Tree-planting and the management of plantations including procurement of private land for exchange of forest land should be entrusted to an independent institution, such as the FPDB. Besides, the capacity of the concerned officials, especially the officials of the district forest offices and the FPDB should be enhanced, and the offices of the protected areas should be built for effectively executing the work of forest clearance, land bank and management of new plantation sites.

\section{References}

APPIIC. 2016. Inception Report. Accelerating Private and Public Investment in Infrastructure Component (APPIIC). IMC Worldwide, Kathmandu, Nepal.

APPIIC. 2017. Report on Stakeholder Consultation on the Use of Forest Land for National Priority Infrastructure. Accelerating Private and Public Investment in Infrastructure Component (APPIIC).
Ministry of Forests and Soil Conservation/ Department for International Development (United Kingdom), Kathmandu, Nepal.

DFRS. 2015. State of Nepal's Forests. Forest Resource Assessment (FRA) Nepal Project, Department of Forest Research and Survey (DFRS), Kathmandu, Nepal.

DoF. 2015. Database (electronic) on Forests Handed Over for Non-Forestry Uses. Department of Forests (DoF), Kathmandu, Nepal.

FPDB. 2016. Official Records (as of November 16, 2016). Forest Products Development Board (FPDB), Kathmandu, Nepal.

MFSC. 1973. National Parks and Wildlife Conservation Act, 2029 B.S. Ministry of Forests and Soil Conservation (MFSC), Kathmandu, Nepal.

MFSC. 1993. Forest Act, 2049 B.S. Ministry of Forests and Soil Conservation (MFSC), Kathmandu, Nepal.

MFSC. 2006. Work Policy to Make Forest Land Available for Other Purposes. Ministry of Forests and Soil Conservation (MFSC), Kathmandu, Nepal.

MFSC. 2009. Work Policy on Infrastructure Development and Operation Within Protected Areas. Ministry of Forests and Soil Conservation, (MFSC), Kathmandu, Nepal.

MFSC. 2014. Forest Policy, 2071. Ministry of Forests and Soil Conservation (MFSC), Kathmandu, Nepal.

MFSC. 2014. Report on the Forests Handed Over to Other Non-Forestry Uses in Nepal. Ministry of Forests and Soil Conservation (MFSC), Kathmandu, Nepal.

MFSC. 2015. Database (electronic) on Forests Handed Over for Non-Forestry Uses. Ministry of Forests and Soil Conservation, Kathmandu (MFSC), Nepal. 